\title{
A retrospective study of reproductive disorders in female dogs from the city of Uberlândia, Minas Gerais, Brazil
}

\section{Estudo retrospectivo de desordens reprodutivas em cadelas no município de Uberlândia, Minas Gerais, Brasil}

\author{
Alisson Souza Costa ${ }^{1}$; Meire Ellen Mendes Silva ${ }^{1}$; Thaisa Reis dos Santos ${ }^{1}$; \\ Mariana Barbosa Bisinoto ${ }^{2}$; Suzana Akemi Tsuruta ${ }^{1}$; Stefânia Beatriz Alves \\ Borges $^{2}$; Sara Pedrosa Franco Barbosa ${ }^{3}$; Aracelle Elisane Alves ${ }^{4}$; Antonio Vicente \\ Mundim ${ }^{4}$; Selwyn Arlington Headley5; João Paulo Elsen Saut ${ }^{4 *}$
}

\begin{abstract}
Diseases of the reproductive system are common in both sexes in the most varied of species. In female dog, these diseases produce different degrees of morbidity and mortality and are influenced by environmental conditions, reproductive history, and previous drug treatments. Reproductive disease may have different consequences, ranging from the absence of clinical signs to the impairment of fertility. The objective of this study was to determine the causes of reproductive diseases in female dogs admitted to the Veterinary Hospital, Federal University of Uberlândia, during a six-year period (2012-2017) and to identify the most frequently occurring diseases. Information relative to the species, age, breed, and sex of 32,944 were obtained for animals. Of these, 16,480 were female dogs and 1,185 were diagnosed with alterations to the reproductive system. The animals were divided into four groups according to age (puppies, young adults, adults, and old) and disease of the reproductive system (Group 1 - vaginal and vulvar alterations; Group 2 - alterations to the estrous cycle, ovary, and uterus; Group 3 - alterations to the gestational period and parturition). The highest occurrence of diagnoses (47\%) was recorded in young adult female dogs ( 1 to 5 years old). The most frequent alterations in female dogs were pyometra (48.8\%), dystocia (13.6\%), and transmissible venereal tumor (TVT) (12.6\%). Crossbred dogs were the most affected with alterations to the reproductive system, representing $60 \%$ of all the female dogs diagnosed with any pathologic alteration. In conclusion, a 7.2\% occurrence of reproductive disorders shows the relevance of these diseases in small animals and suggests that new methods are needed for the prevention, early diagnosis, and treatment of these disorders.
\end{abstract}

Key words: Bitches. Cystic endometrial hyperplasia. Pyometra. Occurrence. TVT.

1 Médicos Veterinários, Hospital Veterinário, Universidade Federal de Uberlândia, UFU, Uberlândia, MG, Brasil. E-mail: alissonsouza@hotmail.com; meireellenms@gmail.com; thaisareis.vetufu@gmail.com; suzanaakemi@yahoo.com.br

2 Médicas Veterinárias, Autônoma, Uberlândia, MG, Brasil. E-mail: marianabisinoto@gmail.com; stefania_beatriz@yahoo. com.br

3 Discente, Curso de Graduação em Medicina Veterinária, Faculdade de Medicina Veterinária, FAMEV, UFU, Uberlândia, MG, Brasil. E-mail: sarapf_vet@outlook.com

4 Profs., FAMEV, UFU, Uberlândia, MG, Brasil. E-mail: aracelle.alves@ufu.br; antoniomundim@ufu.br; jpsaut@ufu.br

5 Prof. Dr., Laboratório de Patologia Animal, Departamento de Medicina Veterinária Preventiva, Universidade Estadual de Londrina, UEL, Londrina, PR, Brasil. E-mail: selwyn.headley@uel.br

* Author for correspondence 


\section{Resumo}

Enfermidades do sistema reprodutor são comuns, para ambos os sexos, nas mais variadas espécies. Em cadelas estas doenças têm diferentes graus de morbidade e mortalidade e são influenciadas por condições ambientais, histórico reprodutivo e tratamentos prévios com fármacos. As afecções reprodutivas podem gerar consequências distintas, variando desde a ausência de sinais clínicos até o comprometimento da fertilidade do animal. Objetivou-se determinar a casuística das enfermidades reprodutivas de cadelas atendidas no Hospital Veterinário da Universidade Federal de Uberlândia, durante seis anos de avaliação (2012-2017), a fim de identificar quais enfermidades eram mais frequentes. Para tanto, foram consultadas informações sobre espécie, idade, raça e sexo de 32.944 animais. Destes, 16.480 eram fêmeas caninas e 1.185 foram diagnosticadas com alterações no sistema reprodutivo. Os animais foram divididos de acordo com a idade em quatro grupos (filhotes, adultos jovens, adultos e idosos); e com as enfermidades do sistema reprodutivo (Grupo 1 - alterações de vagina e vulva; Grupo 2 - alterações de ciclo estral, ovário e útero; Grupo 3 - alterações do período gestacional e parto). As médias de idades que apresentaram maior ocorrência de diagnósticos foram em cadelas adultas jovens ( 1 a 5 anos) com $47 \%$. As patologias mais frequentes em fêmeas caninas foram a piometra $(48,8 \%)$, distocias $(13,6 \%)$ e Tumor Venéreo Transmissível (TVT) (12,6\%). Os animais mestiços (SRD) foram os mais acometidos por distúrbios do sistema reprodutor, representando $60 \%$ do total de fêmeas diagnosticadas. Concluiu-se que a ocorrência de $7,2 \%$ de desordens reprodutivas mostra a relevância dessas doenças na clínica de pequenos animais e contribui para o reconhecimento de que novos métodos de prevenção, diagnóstico precoce e tratamento dessas desordens são necessários.

Palavras-chave: Cadelas. Hiperplasia endometrial cística. Piometra. Prevalência. TVT.

\section{Introduction}

As a result of urbanization, modern society has been through constant changes including the development of close relationships between humans and pets; this makes pets important components of social relationships, and there is increasing demand for the maintenance of breeds appropriate for specific purposes, such as company, sport, hunting, and/or guarding, as well as aiding the disabled and the elderly. Therefore, preserving the reproductive capacity of pet animals is of great importance, considering their genetic and zootechnical value (BRITO FILHO, 2008; STALLIVIERE et al., 2013).

Brazil has the second largest dog population globally, with an estimated 52.2 million dogs, only surpassed by the US, and it is estimated that $44.3 \%$ of Brazilian households own a dog; according to the PNAD (Pesquisa Nacional de Amostra de Domicílios - Brazilian National Household Sample Survey) conducted by IBGE (2013), dogs even outnumber children (44.9 million) in Brazilian households.
Consequently, it is important that studies are done to assess the occurrence of disorders that affect these animals to establish new guidelines regarding prevention, diagnosis, and treatment. Veterinarians frequently find lesions in the female reproductive tracts in their routine practice, and these lesions can progress at any stage of the reproductive life of the animals (ORTEGA-PACHECO et al., 2012).

In female dogs, these diseases produce different degrees of morbidity and mortality and are influenced by environmental conditions, reproductive history, and previous treatments with drugs, resulting in regional variations in the prevalence of some reproductive abnormalities (PREVIATO et al., 2005). Moreover, dogs are particularly susceptible to the deleterious effects of sexual steroids, and the stimulation of progesterone and estradiol in the ovarian and uterine epithelium during consecutive estrous cycles is a risk factor for the establishment of proliferative conditions in these tissues, as well as in the epithelium and stroma of the mammary glands (MAYA-PULGARIN et al., 2017). 
Reproductive diseases can have different consequences, ranging from the asymptomatic manifestation and impairment of fertility to acute clinical manifestations that can result in death (NASCIMENTO; SANTOS, 2003). The main clinical alterations observed in female dogs include estrous cycle disorders (ovarian remnant syndrome and pseudocyesis), vaginal and uterine disorders (vaginitis, uterine torsion, cystic endometrial hyperplasia, and pyometra), and intrapartum and postpartum disorders (dystocia, agalactia, puerperal tetany, metritis, and abortions) (NELSON; COUTO, 2015; BIDDLE; MACINTIRE, 2000).

According to data from the FORDHOV (FORDHOV, 2018), Brazil has 50 veterinary hospitals in federal higher education institutions. Therefore, studies on disease occurrences are important to determine their relevance for the health of animals, as well as to identify risk factors and guide future studies aiming to establish better diagnostic and therapeutic approaches for these patients.

The objective of this study was to determine the causes of reproductive diseases in female dogs that attended the Veterinary Hospital, Federal University of Uberlândia during a six-year assessment period (2012-2017) in order to provide concrete data that may contribute to the characterization of the profile of the affected animals, enabling the prevention and early diagnosis of these reproductive disorders.

\section{Material and Methods}

A total of 32,944 records of animals routinely attended at the Small Animal Clinic of the Veterinary Hospital, Universidade Federal de Uberlândia (HVUFU), Minas Gerais, Brazil, were consulted during January 2012 to December 2017.

During the retrospective assessment of the clinical records of the animals, data relating to species, age, breed, and gender of each animal were collected for those animals presenting diagnoses related to the female reproductive system. This study did not include animals diagnosed with mammary gland alterations since the objective was to specifically assess disorders of the uterus, ovaries, vagina, and vulva, as well as estrous, gestational, and post-partum alterations, according to which animals were assembled into three different groups for analysis.

The diagnoses were based on the evaluation of anamneses, general physical examinations, specific physical examination of the reproductive system, and complementary exams such as ultrasonography, radiography, and cytopathological. Specifically, for cystic endometrial hyperplasia (CEH), pyometra, hematometra, and mucometra complex, the following complementary exams were recommended: complete blood count, serum creatinine, and abdominal ultrasonography. Transmissible venereal tumor (TVT) was diagnosed by physical examination, via inspection of the tumor at the genitalia by cytopathological exams including microscopy slide imprinting and fineneedle aspiration cytology (FNAC).

The animals were assigned to four age groups: pups (less than one year old), young adults (one to five years old), adults (six to nine years old), and elderly (over nine years old). Regarding the diseases diagnosed, the animals were divided into three groups: Group 1: vaginal and vulvar alterations; Group 2: estrous cycle, ovarian, and uterine alterations; and Group 3: gestation and partum alterations (BRITO FILHO, 2008). The data were summarized in Microsoft Excel 2010 spreadsheets and submitted for descriptive statistical analysis.

\section{Results}

During the six-year assessment period (20122017), 32,944 animals attended the clinic, of which $84.9 \%(n=27,973)$ were dogs, and $58.9 \%$ $(n=16,480)$ of these, were females. Of the total number of female dogs, $7.2 \%(1,185 / 16,480)$ were 
diagnosed with diseases of the reproductive system. There were variations in the annual occurrences of reproductive disorders in each group of female dogs; these variations were most pronounced during 2013 (Table 1).
Regarding breed variation, among the 1,185 female dogs diagnosed with diseases of the reproductive system, $60.1 \%$ were crossbreeds $(n=712), 9.96 \%$ Poodles $(n=118), 7.59 \%$ Pinschers $(\mathrm{n}=90), 4.98 \%$ Shih Tzus ( $\mathrm{n}=59), 3.46 \%$ Pit Bulls $(n=41)$, and $13.93 \%(n=165)$ other breeds (Figure 1).

Table 1. Occurrence of reproductive disorders in female dogs attended at the Veterinary Hospital, Universidade Federal de Uberlândia, Uberlândia, Minas Gerais, Brazil (2012-2017).

\begin{tabular}{ccccccc}
\hline & \multicolumn{5}{c}{ Female dogs with reproductive disorders } \\
\cline { 2 - 6 } & $2012 \%(n)$ & $2013 \%(n)$ & $2014 \%(n)$ & $2015 \%(n)$ & $2016 \%(n)$ & $2017 \%(n)$ \\
\hline \multirow{2}{*}{ Female dogs } & $7.04 \%$ & $9.02 \%$ & $6.06 \%$ & $7.15 \%$ & $7.57 \%$ & $6.13 \%$ \\
& $(179 / 2,540)$ & $(268 / 2,969)$ & $(183 / 3,018)$ & $(185 / 2,586)$ & $(215 / 2,840)$ & $(155 / 2,527)$ \\
\hline
\end{tabular}

Figure 1. Distribution of the occurrence of reproductive disorders according to the breed of female dog that attended the Veterinary Hospital of Universidade Federal de Uberlândia, Uberlândia, Minas Gerais, Brazil (2012-2017).

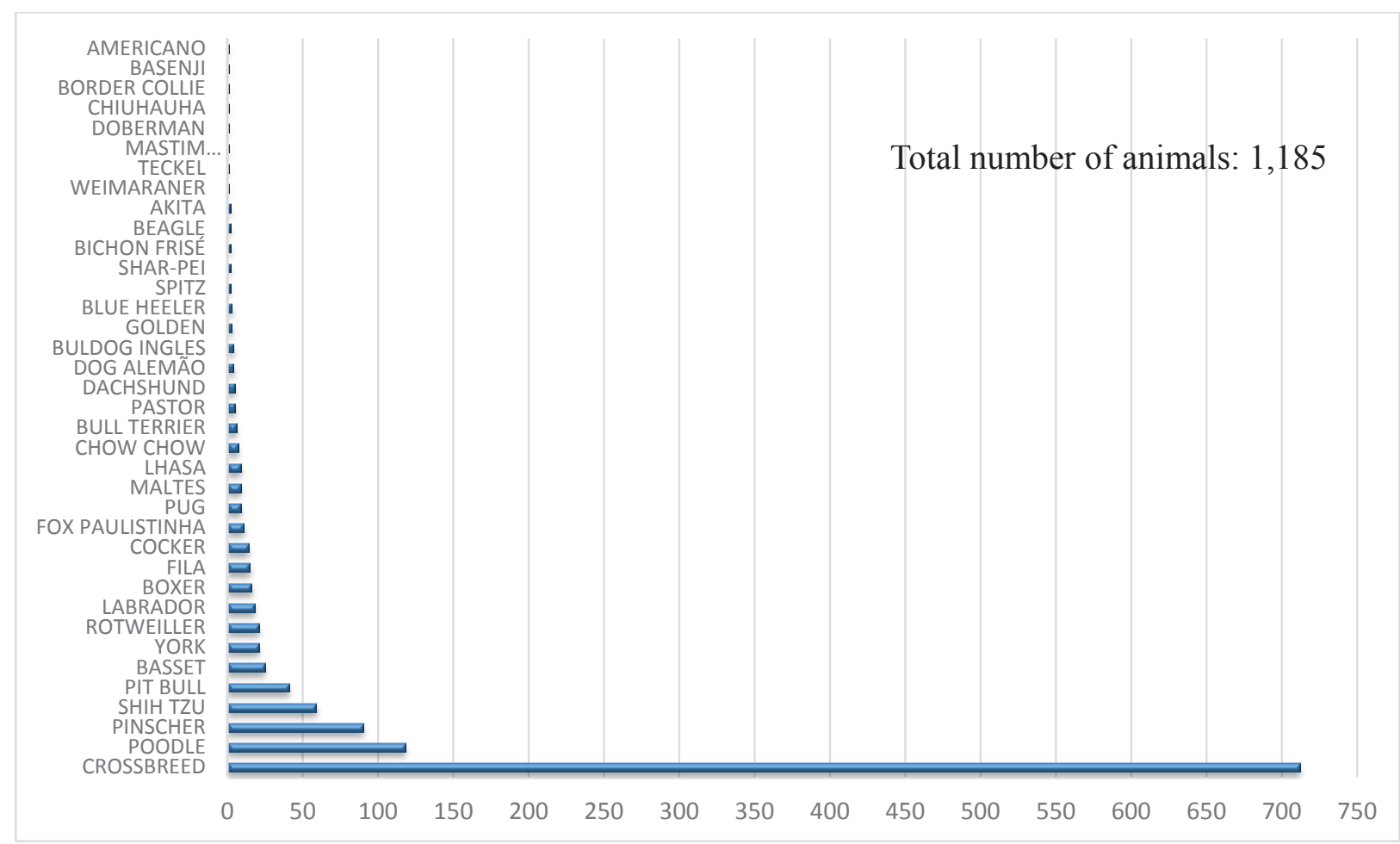

Female dogs that attended the HV-UFU during this period showed a mean age of $6.62 \pm 3.61$ years. The age distribution of the animals (pups, young adults, adults, and elderly), is shown in Figure 2 and revealed that the highest occurrence of reproductive diseases were in young adult female dogs $(47 \%$, $557 / 1,185)$, followed by elderly female dogs $(29.4 \%, 348 / 1,185)$, adults $(22.5 \%, 267 / 1,185)$, and pups $(1.1 \%, 13 / 1,185)$. 
The 1,185 female dogs were grouped according to reproductive disorder (Table 2). The three diseases with the highest incidence in the female dogs were pyometra $(48.8 \%, \mathrm{n}=578)$, dystocia $(13.6 \%, \mathrm{n}=161)$, and TVT $(12.6 \%, \mathrm{n}=150)$.
Comparison of the three groups of reproductive disorders (Table 2) showed that disease occurrence was highest in young adults in both Group 1, with $60.6 \%$ (123/203), and Group 3, with $73.4 \%$ $(163 / 222)$, whereas in Group 2, there was a higher disease occurrence in elderly animals, with a value of $40.1 \%(305 / 760)$.

Figure 2. Occurrence of reproductive disorders by group according to the age range of the female dogs that attended the Veterinary Hospital of Universidade Federal de Uberlândia, Uberlândia, Minas Gerais, Brazil (2012-2017).

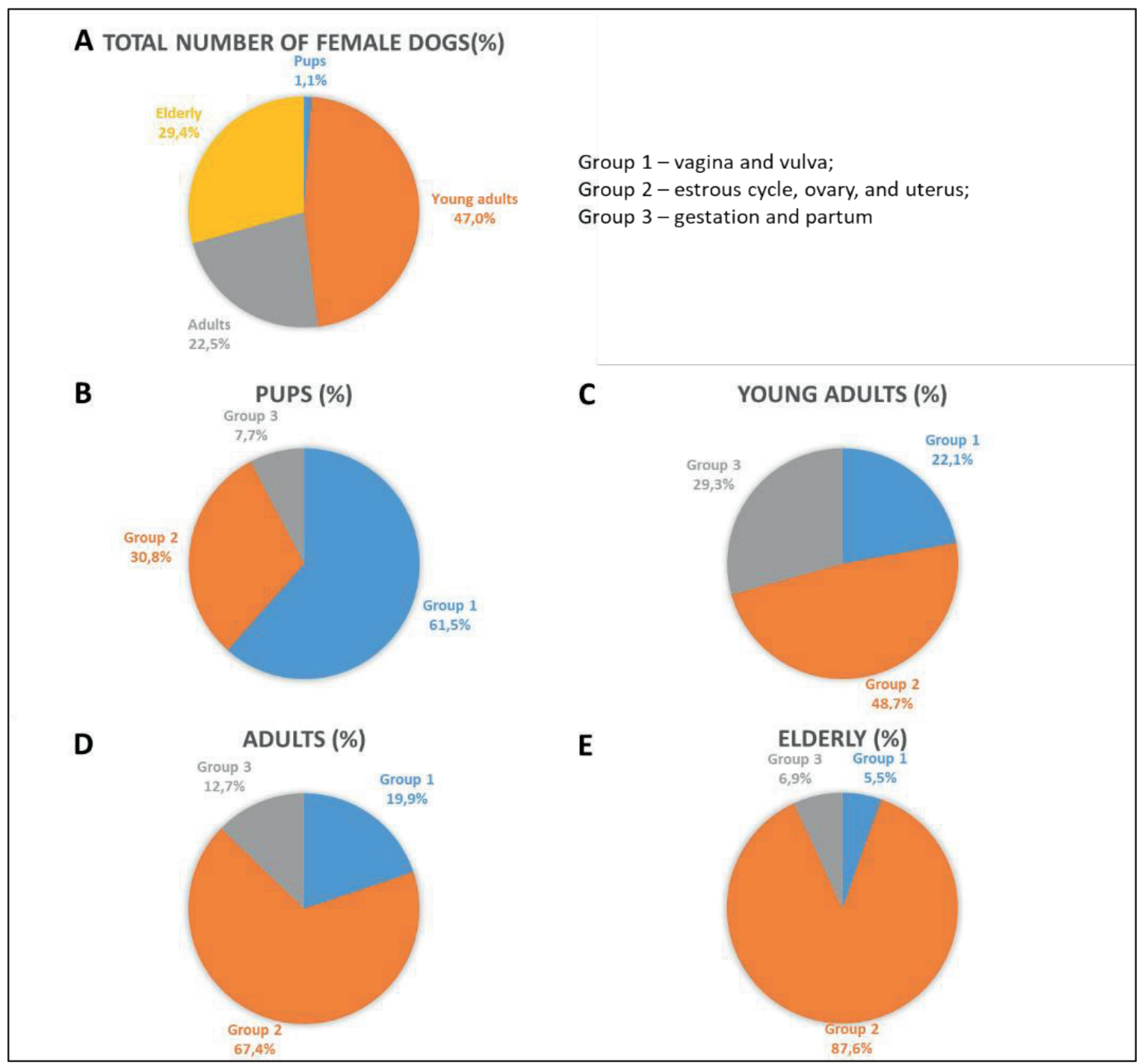

Pups: female dogs under one year of age; young adults: female dogs between one and five years of age; adults: female dogs between six and nine years of age; and elderly: female dogs over nine years of age. 
Table 2. Distribution of diagnoses by groups of reproductive disorders in female dogs that attended the Veterinary Hospital of Universidade Federal de Uberlândia, Uberlândia, Minas Gerais, Brazil (2012-2017).

\begin{tabular}{lcc}
\hline \multicolumn{1}{c}{ DISORDER } & FEMALE DOGS \\
\cline { 2 - 3 } & $\%(\mathrm{n})$ & AGE \\
\hline GROUP 1 (n=203) & & \\
TVT & $73.89(150)$ & $5.44 \pm 2.45$ \\
Vaginitis & $18.23(37)$ & $2.46 \pm 0.93$ \\
Vaginal prolapse & $6.40(13)$ & $5.87 \pm 4.67$ \\
Vaginal hyperplasia & $1.48(3)$ & $5 \pm 1.41$ \\
\hline GROUP 2 (n=760) & & \\
Pyometra & $76.05(578)$ & $8.10 \pm 3.44$ \\
Pseudocyesis & $11.32(86)$ & $5.83 \pm 3.71$ \\
CEH & $4.61(35)$ & $7.14 \pm 3.64$ \\
Hematometra & $3.55(27)$ & $7.31 \pm 3.36$ \\
Stump pyometra & $0.92(7)$ & $5.4 \pm 4.16$ \\
Uterine prolapse & $0.66(5)$ & $2.67 \pm 1.15$ \\
Remnant ovary & $1.05(8)$ & $4.0 \pm 1.41$ \\
Endometritis & $0.39(3)$ & $5.0 \pm 0.0$ \\
Postpartum metritis & $0.39(3)$ & $2.5 \pm 2.12$ \\
Ovarian cyst & $0.66(5)$ & $9.0 \pm 0.0$ \\
Mucometra & $0.39(3)$ & $11.0 \pm 0.0$ \\
\hline GROUP 3 (n=222) & & \\
Dystocia & $72.52(161)$ & $4.56 \pm 2.57$ \\
Dystocia with dead fetus & $7.66(17)$ & $5.79 \pm 2.81$ \\
Abortion & $6.31(14)$ & $4.0 \pm 3.16$ \\
Macerated fetus & $12.16(27)$ & $4.6 \pm 2.59$ \\
Mummified fetus & $1.35(3)$ & $3.0 \pm 0.0$ \\
\hline No: Grop 1- van & \\
\hline
\end{tabular}

Note: Group 1 - vaginal and vulvar alterations; Group 2 - estrous cycle, ovarian, and uterine alterations; Group 3 - gestational and partum alterations.

\section{Discussion}

The occurrence of reproductive disorders observed in this study $(7.2 \%)$ is in agreement with a study by Rosa Júnior et al. (2011) that showed a $7.65 \%$ incidence of reproductive disorders in animals that attended the Veterinary Clinic of the Universidade Federal de Pelotas, Rio Grande do Sul, Brazil, as well as with a study by Montenegro (2010), who showed a $4.3 \%$ disease occurrence at the Veterinary Hospital of Montenegro, Vila Real, Portugal.

Of the diseases related to vaginal and vulvar disorders (Group 1), canine TVT had the highest occurrence $(73.9 \%)$. This lesion is a transplantable neoplasm of round cells that is disseminated in the population mainly through sexual contact. Huppes et al. (2014) revealed that $59 \%$ of dogs diagnosed with TVT were of the mixed breed, females were more affected than males, and dogs within the 2-8 age group were more frequently affected. These results are similar to those of the present study, since $80.6 \%$ (121/150) were crossbred female dogs with a mean age of $5.4 \pm 2.4$ years; similar findings were described by Amaral et al. (2004) and TinucciCosta (2009). 
In vaginal and vulvar alterations (Group 1) there was a higher occurrence of vaginitis $(1.97 \%, 4 / 203)$ in younger animals ( $<1$-year-old), which can be related to the immaturity of the reproductive tract since this is one of the etiologies for this medical condition (JOHNSON, 2006).

In uterine, ovarian, and estrous cycle alterations (Group 2), pyometra was predominant, affecting $76 \%$ of all the female dogs in this group, with an average age of $8.1 \pm 3.4$ years. Trautwein et al. (2017) studied pyometra in female dogs and related the mean age of $8.4 \pm 3.5$ years; these findings are similar to the results of the current study. Additionally, Montenegro (2010), in a similar study, found a greater occurrence of pyometra in $52 \%$ of female dogs, with a mean age of $8.6 \pm 3.4$ years. Fukuda (2001) described an incidence of $15.2 \%$ $(25 / 165)$ for pyometra in females over 4 years old, whereas Hagman (2018) related that pyometra affected more middle-aged female dogs, usually four months after estrous, than elderly, unspayed female dogs.

Jitpean et al. (2012) suggested that pyometra can affect up to $19 \%$ of unspayed female dogs under the 10 years of age. Moreover, Egenvall (2001) demonstrated that pyometra occurs in $25 \%$ of unspayed female dogs and is the most common uterine disease in these animals.

The Cystic Endometrial Hyperplasia hematometra, mucometra, and pyometra complex was the most frequent alteration in female dogs in this study, accounting for $84.6 \%$ of the female dogs in Group 2 (643/760); these findings are in agreement with a study by Maya-Pulgarin et al. (2017) that demonstrated that pyometra was the most frequent non-neoplastic uterine alteration and was observed histologically in $19.7 \%$ of uteruses of clinically healthy female dogs submitted to elective ovarian salpingo hysterectomy (OSH). In the present study, the mean age of the female dogs diagnosed with $\mathrm{OSH}$ was $7.97 \pm 3.47$ years. Although $\mathrm{OSH}$ was reported in female dogs between 4 months and 18 years, this disorder affects middle age and elderly females with a greater frequency, with a mean age of 7 years (HAGMAN, 2018). These data support the findings of our study in which animals above 9 years of age in Group 2 had a higher disease incidence $(40.1 \%)$ of OSH.

Regarding gestational and partum alterations, the most frequent disease was dystocia, which is defined as the inability of the bitch to expel the fetus through the vagina during birth, regardless of the cause, which can be maternal, fetal, or both (LUZ et al., 2016). The occurrence of dystocia in gestating female varies between $5 \%$ to $6 \%$ (SILVA, 2008); however, in the present study, $80.2 \%(178 / 222)$ of the female dogs presented this disorder, while Montenegro (2010) found a 35\% (41\%) incidence of dystocia in reproductive urgency visits in a retrospective study, while Hollinshead and Hanlon (2017) described a 26\% (232/890) occurrence of dystocia.

Pure and small breeds are more predisposed to dystocia than crossbreeds (SILVA, 2008; LUZ et al., 2016). However, the animals that routinely attended the HV-UFU were mostly of undefined breed and our study showed that $58.4 \%$ of the female dogs with dystocia were crossbreeds, $12.9 \%$ were Pinschers, and $28.6 \%$ were of other breeds. Several maternal and fetal factors may contribute to dystocia; according to Darvelid and Linde-Forsberg (1994), $75 \%$ of cases in female dogs are of maternal and $25 \%$ of fetal origin, with uterine inertia and poor fetal presentation being the main causes of this disease.

In the present study, $73.3 \%$ of the female dogs with reproductive diseases were indicated for hysterectomy, with $74 \%$ the $\mathrm{CEH}$ complex (643/869), 20.5\% dystocia (178/869), 3.1\% fetal maceration (27/869), $1.5 \%$ vaginal prolapse $(13 / 869), \quad 0.58 \%$ uterine prolapse $(5 / 869)$, and $0.34 \%$ mummified fetus $(3 / 869)$.

In this study, abortion occurred in $6.31 \%$ $(14 / 222)$ of the female dogs in Group 3, which 
is similar to the $6.8 \%(2,771 / 40,748)$ described by Chastant-Maillard et al. (2016). Although the causes of abortion were not investigated in this study, the incidence of abortions, stillbirths, and neonatal mortality are known to vary from 5\% to $35 \%$; the origin of these losses is complex and can be divided into infectious and non-infectious causes, even though the etiology of many cases were not identified. Among infectious disease pathogens, Staphylococcus spp., Streptococcus spp., Escherichia coli, Brucella canis, Campylobacter spp., and Salmonella spp., are the most frequently isolated, whereas canine herpesvirus- 1 and canine parvovirus-2 are among the most common viral causes (STEFANETTI et al., 2018); moreover, canine distemper virus (CDV) was associated with reproductive diseases (KRAKOWKA et al., 1974), and confirmed as a reproductive disease agent of the female reproductive system of the dog (KRAKOWKA et al., 1977). Santos et al. (2014) demonstrated that $10 \%$ of a population had active herpesvirus type 1 infections and some degree of reproductive alteration, confirming the circulation of the virus in the canine population in Uberlândia, Minas Gerais, and the possible link with these disorders, which has also been reported in other studies on herpesvirus type 1 infections (RONSSE et al., 2005; DAHLBOM et al., 2009).

Studies done in the city of Uberlândia found that the occurrence of leptospirosis in dogs was $46 \%$ (SOUZA et al., 2008); this disease, in addition to be a zoonosis, produces reproductive disorders in dogs (CASTRO et al., 2011).

The transmission of these infectious-contagious diseases is related to the management, population density, and vaccination status of the animals (CASTRO et al., 2011). It is important that serological and molecular tests are done to improve diagnoses and thus avoid the transmission of these infectious diseases. Although diagnoses of infectious diseases that affects the reproductive system, such as brucellosis, herpes virus-1 infections, and leptospirosis (SHIN; CARMICHAEL, 1999;
DAHLBOM et al., 2009; CASTRO et al., 2011), were not investigated in this study, these diseases should be investigated in the future in the analyzed population.

\section{Conclusion}

The $7.2 \%$ occurrence of reproductive disorders shows the relevance of these diseases in small animal clinical practice and highlights that new methods are needed for the prevention, early diagnosis, and treatment of these disorders.

\section{References}

AMARAL, A. S.; GASPAR, L. F. J.; SILVA, S. B.; ROCHA, N. S. Diagnóstico citológico do tumor venéreo transmissível na região de Botucatu, Brasil (estudo descritivo : 1994-2003). Revista Portuguesa de Ciências Veterinárias, Lisboa, v. 99, n. 551, p. 167-171, 2004.

BIDDLE, D.; MACINTIRE, D. K. Obstetrical emergencies. Clinical Techniques in Small Animal Practice, Amsterdan, v. 15, n. 2, p. 88-93, maio 2000. DOI: $10.1053 / \mathrm{svms} .2000 .6803$

BRITO FILHO, F. B. Estudo retrospectivo das enfermidades relacionadas à clínica da reprodução de pequenos animais no periodo de 2001-2007 no hv-CstrUfcg. 2008. Monografia (Trabalho de Conclusão de Curso de Graduação em Medicina Veterinária) - Universidade Federal de Campina Grande, Patos.

CASTRO, J. R.; SALABERRY, S. R. S.; SOUZA, M. A.; LIMA-RIBEIRO, A. M. C. Sorovares de Leptospira spp. predominantes em exames sorológicos de caninos e humanos no município de Uberlândia, Estado de Minas Gerais. Revista da Sociedade Brasileira de Medicina Tropical, Brasília, v. 44, n. 2, p. 217-222, 2011. DOI: $10.1590 / \mathrm{S} 0037-86822011005000012$

CHASTANT-MAILLARD， S.; GUILLEMOT， C.; FEUGIER, A.; MARIANI, C.; GRELLET, A.; MILA, H. Reproductive performance and pre-weaning mortality: preliminary analysis of 27,221 purebred female dogs and 204,537 puppies in France. Reproduction in Domestic Animals, Tolouse, v. 51, n. 3, p. 1-5, 2016. DOI: 10.1111/ rda. 12845

DAHLBOM, M.; JOHNSSON, M.; MYLLYS, V.; TAPONEM, J.; ANDERSSON, M. Seroprevalence of canine herpesvirus-1 and Brucella canis in Finnish breeding kennels with and without reproductive 
problems. Reproduction in Domestic Animals, Oxford, v. 44, n. 1, p. 128-131, fev. 2009. DOI: 10.1111/j.14390531.2007.01008.x

DARVELID, A. W.; LINDE-FORSBERG, C. Dystocia in the bitch: a retrospective study of 182 cases. Journal of Small Animal Practice, Oxford, v. 35, n. 8, p. 402-407, 1994. DOI: 10.1111/j.1748-5827.1994.tb03863.

EGENVALL, A.; HAGMAN, R.; BONNETT, B. N.; HEDHAMMAR, A.; OLSON, P.; LAGERSTEDT, A. $\mathrm{S}$. Breed risk of pyometra in insured dogs in Sweden. Journal of Veterinary Internal Medicine, Geenwood Village, v. 15, n. 6, p. 530-538, 2001. DOI: 10.1111/ j.1939-1676.2001.tb01587.x

FÓRUM DOS DIRIGENTES DE HOSPITAIS VETERINÁRIOS DE INSTITUIÇÕES FEDERAIS DE ENSINO SUPERIOR - FORDHOV. XV Fórum dos Dirigentes de Hospitais Veterinários de Instituições Federais de Ensino Superior. Pelotas: UFPel, 2018. Disponível em: https://wp.ufpel.edu.br/ fordhovufpel/. Acesso em: 30 jan. 2019.

FUKUDA, S. Incidence of pyometra in colonyraised beagle dogs. Experimental Animals / Japanese Association for Laboratory Animal Science, Tokyo, v. 50, n. 4, p. 325-329, 2001. DOI: 10.1538/expanim.50.325

HAGMAN, R. Pyometra in small animals. Veterinary Clinics of North America: Small Animal Practice, Philadelphia, v. 48, n. 4, p. 639-661, 2018. DOI: 10.1590/1089-6891v18e-44302

HOLLINSHEAD, F. K.; HANLON, D. W. Factors affecting the reproductive performance of bitches: a prospective cohort study involving 1203 inseminations with fresh and frozen semen. Theriogenology, Matamata, v. 101, n. 1, p. 62-72, 2017. DOI: 10.1016/j. theriogenology.2017.06.021

HUPPES, R. R.; SILVA, C. G.; USCATEGUI, R. A. R.; DE NARDI, A. B.; SOUZA, F. W.; TINUCCI- COSTA, M.; AMORIM, R. L.; PAZZINI, J. M.; FARIA, J. L. M. Tumor venéreo transmissível (TVT): estudo retrospectivo de 144 casos. ARS Veterinária, Jaboticabal, v. 10, n. 1, p. $13-18,2014$. DOI: 10.15361/2175-0106.2014v30n $1 \mathrm{p} 13-18$

INSTITUTO BRASILEIRO DE GEOGRAFIA E ESTATÍSTICA - IBGE. Diretoria de pesquisas, coordenação de trabalho e rendimento: pesquisa nacional de saúde. Rio de Janeiro: IBGE, 2013. Disponível em: http://ftp.ibge.gov.br/PNS/2013/pns2013.pdf. Acesso em: 2 jun. 2015.

JITPEAN, S.; HAGMAN, R.; STRÖM HOLST, B.; HÖGLUND, O. V.; PETTERSSON, A.; EGENVALL, A. Breed variations in the incidence of pyometra and mammary tumours in swedish dogs. Reproduction in Domestic Animals, Berlin, v. 47, p. 347-350, 2012. Suplement 6. DOI: 10.1111/rda.12103

JOHNSON, C. A. Distúrbios do sistema reprodutivo. In: NELSON, R. W.; COUTO, C. G. Medicina interna de pequenos animais. 3. ed. Rio de Janeiro: Editora Roca, 2006. p. 811-911.

KRAKOWKA, S.; CONFER, A; KOESTNER, A. Evidence for transplacental transmission of canine distemper virus: two case reports. American Journal of Veterinary Research, Ohio, v. 35, n. 9, p. 1251-1253, 1974. DOI: $10.1590 /$ S1413-95962000000200009

KRAKOWKA, S.; HOOVER, E. A.; KOESTNER, A.; KETRING, K. Experimental and naturally occurring transplacental transmission of canine distemper virus. American Journal of Veterinary Research, Ohio, v. 38, n. 7, p. 919-922, 1977.

LUZ, M. R.; MÜNNICH, A.; VANNUCCHI, C. I. Novos enfoques na distocia em cadelas. Revista Brasileira de Reprodução Animal, Belo Horizonte, v. 39, n. 3, p. 354361, 2015.

MAYA-PULGARIN, D; GONZALEZ-DOMINGUEZ, M. S.; ARANZAZU-TABORDA, D.; MENDONZA, N.; MALDONADO-ESTRADA, J. G. Histopathologic findings in uteri and ovaries collected from clinically healthy dogs at elective ovariohysterectomy: a cross-sectional study. Journal of Veterinary Science, Medellin, v. 18, n. 3, p. 407-414, 2017. DOI: 10.4142\%2Fjvs.2017.18.3.407

MONTENEGRO, L. M. F. Estudo retrospectivo de urgências reprodutivas no Hospital Veterinário Montenegro. 2010. Dissertação (Mestrado em Medicina Veterinária) - Universidade de Trás-os-Montes e Alto Douro, Vila Real.

NASCIMENTO, E. F.; SANTOS, R. L. Patologia da reprodução dos animais domésticos. 2. ed. Rio de Janeiro: Guanabara Koogan, 2003. 137 p.

NELSON, R. W.; COUTO, C. G. Distúrbios do sistema reprodutor. In: NELSON, R. W.; COUTO, C. G. (Ed.). Medicina interna de pequenos animais. 5. ed. Rio de Janeiro: Elsevier, 2015. p. 897-962.

ORTEGA-PACHECO, A.; GUTIÉRREZ-BLANCO, E.; JIMÉNEZ-COELLO, M. Common lesions in the female reproductive tract of dogs and cats. Veterinary Clinics of North America: Small Animal Practice, Mérida, v. 42, n. 3, p. 547-559, 2012. DOI: 10.1016/j.cvsm.2012.01.011

PREVIATO, P.; PINTO NETO, A.; WERNER, P. R.; ACCO, A.; MOTA, M. F.; SILVA, A. V.; FONSECA, J. F. Alterações morfológicas nos órgãos genitais de cães e gatos provenientes de vilas rurais da região de 
Umuarama-PR. Arquivos de Ciências Veterinárias e Zoologia UNIPAR, Umuarama, v. 8, n. 2, p. 105-110, 2005. DOI: 10.25110 /arqvet.v8i2.2005.46

RONSSE, V.; VERSTEGEN, J.; THIRY, E.; ONCLIN, K.; AEBERLÉ, C.; BRUNET, S.; POUlET, H. Canine herpesvirus-1 (CHV-1): clinical, serological and virological patterns in breeding colonies. Theriogenology, Philadelphia, v. 64, n. 1, p. 61-74, 2005. DOI: 10.1016/j. theriogenology.2004.11.016

ROSA JÚNIOR, A. S.; FERRASSO, M. M.; CARNEVALI, T. R.; FERNANDES, C. P. M.; AZAMBUJA, R. H. M.; CLEFF, M. B. Casuística do atendimento a pequenos animais no ambulatório veterinário - UFPEL. In: CONGRESSO BRASILEIRO DE MEDICINA VETERINÁRIA, CONBRAVET, 38., 2011, Florianópolis. Anais.... Florianópolis: SOVERGS, 2011. Disponível em: www.sovergs.com.br/site/38 conbravet/resumo/990.pdf. Acesso em: 26 maio 2015.

SANTOS, T. R. Detecção molecular do herpesvírus canino tipo-1 em cadelas com histórico de desordens reprodutivas no sudeste do Brasil. 2014. Dissertação (Mestrado em Ciências Agrárias) - Universidade Federal de Uberlândia, Uberlândia.

SHIN, S.; CARMICHAEL, L. E. Canine brucellosis caused by Brucella canis. In: CARMICHAEL, L. E. (Ed.). Recent advances in canine infectious disease. New York: Internacional Veterinary Information Service, 1999. p. 1-4. Disponível em: http://www.ivis.org/ advances/Infect_Dis_Carmichael/shin/\% 0 chapter_frm. asp $\% 20$ ?LA=1\%3E. Acesso em: 24 mar. 2018.

SILVA, S. B. Emergências do trato reprodutivo feminino. In: SANTOS, M. M.; FRAGATA, F. S. Emergência e terapia intensiva veterinária em pequenos aninais: bases para o atendimento hospitalar. Rio de Janeiro: Editora Roca, 2008. p. 330-341.
SOUZA, M. A.; RIBEIRO, V. C.; LIMA, A. M. C.; CASTRO, J. R.; MOREIRA, R. Q.; SALABERRY, S. R. S.. Prevalência de leptospirose em cães no municipio de Uberlândia, Minas Gerais, Brasil. In: SEMANA DO SERVIDOR E SEMANA ACADÊMICA DA UNIVERSIDADE FEDERAL DE UBERLÂNDIA, 4., 5., 2008, Uberlândia. Anais... Uberlândia: Edufu, 2008. p. 1-8. Disponível em: https://ssl4799.websiteseguro .com/swge5/seg/cd2008/PDF/SA08-10890.PDF. Acesso em: 25 jul. 2017.

STALLIVIERE, F. M.; DALLA ROSA, L.; BELLATO, V.; SOUZA, A. P.; SARTOR, A. A.; MOURA, A. B. Helmintos intestinais em cães domiciliados e aspectos socioeconômicos e culturais das famílias proprietárias dos animais de Lages, SC, Brasil. Archives of Veterinary Science, Curitiba, v. 18, n. 3, p. 22-27, 2013. DOI: 10.5380/avs.v18i3.28720

STEFANETTI, V.; COMPAGNONE, A.; SORDINI, C.; PASSAMONTI, F.; RAMPACCI, E.; MOSCATI, L.; MARENZONI, M. L. Retrospective biomolecular investigation of Coxiella burnetii and Leptospira spp. DNA in cases of abortion, stillbirth and neonatal mortality in dogs and cats. Topics in Companion Animal Medicine, Perugia, v. 33, n. 4, p. 122-125, 2018. DOI: 10.1053/j. tcam.2018.08.005

TINUCCI-COSTA, M. T. Tumor venéreo transmissível canino. In: DELECK, C. R.; NARDI, A. B. de; RODASKI, S. Oncologia em cães e gatos. São Paulo: Editora Roca, 2009. p. 540-551.

TRAUTWEIN, L. G. C.; SANT'ANNA, M. C.; JUSTINO, R. C.; GIORDANO, L. C. P.; FLAIBAN, K. K. M. C.; MARTINS, M. I. M. Piometras em cadelas: relação entre o prognóstico clínico e o diagnóstico laboratorial. Ciência Animal Brasileira, Goiânia, v. 18, n. 1, p. 1-10, 2017. DOI: 10.1590/1809-6891v18e-44302 